Article

\title{
Structural and Conformational Studies on Carboxamides of 5,6-Diaminouracils-Precursors of Biologically Active Xanthine Derivatives
}

\author{
Daniel Marx ${ }^{1,2}$, Gregor Schnakenburg ${ }^{3}$, Stefan Grimme ${ }^{4}\left[\mathbb{D}\right.$ and Christa E. Müller ${ }^{1,2, * \mathbb{C}}$ \\ 1 Pharmaceutical Institute, Pharmaceutical Chemistry I, University of Bonn, D-53121 Bonn, Germany; \\ dmarx@uni-bonn.de \\ 2 Pharma Center Bonn, University of Bonn, D-53121 Bonn, Germany \\ 3 Department of Chemistry, Institute of Inorganic Chemistry, University of Bonn, D-53121 Bonn, Germany; \\ gregor.schnakenburg@uni-bonn.de \\ 4 Mulliken Center for Theoretical Chemistry, Institute of Physical and Theoretical Chemistry, \\ University of Bonn, D-53115 Bonn, Germany; grimme@thch.uni-bonn.de \\ * Correspondence: christa.mueller@uni-bonn.de; Tel.: +49-0228-732-301
}

Academic Editor: F. Javier Luque

check for updates

Received: 2 May 2019; Accepted: 4 June 2019; Published: 9 June 2019

\begin{abstract}
Arylethynylxanthine derivatives are potent, selective adenosine $\mathrm{A}_{2 \mathrm{~A}}$ receptor antagonists, which represent (potential) therapeutics for Parkinson's disease, Alzheimer's dementia, and the immunotherapy of cancer. 6-Amino-5-amidouracil derivatives are important precursors for the synthesis of such xanthines. We noticed an unexpected duplication of NMR signals in many of these uracil derivatives. Here, we present a detailed analytical study of structurally diverse 6-amino-5-carboxamidouracils employing dynamic and two-dimensional NMR spectroscopy, density functional theory calculations, and X-ray analysis to explain the unexpected properties of these valuable drug intermediates.
\end{abstract}

Keywords: amide; DFT calculation; dynamic NMR; rotamers/conformers; uracil; xanthine; X-ray crystallography

\section{Introduction}

The nucleoside adenosine is an important (patho)physiological modulator in the brain as well as in peripheral tissues and organs [1]. It activates $G$ protein-coupled adenosine receptors (ARs) which comprise $A_{1-}, A_{2 A^{-}}, A_{2 B^{-}}$, and $A_{3} A R$ subtypes. The $A_{2 A} A R$ subtype has become a major (potential) drug target. $\mathrm{A}_{2 \mathrm{~A}} \mathrm{AR}$ antagonists have been developed for neurodegenerative diseases such as Parkinson's [2] and Alzheimer's disease [3], and, recently, their great potential for the immunotherapy of cancer has been discovered [4]. The first identified AR antagonists were the natural alkaloids caffeine (1,3,7-trimethylxanthine, 1) and theophylline (1,3-dimethylxanthine, 2) (Figure 1) [5]. After discovering these alkylxanthines as moderately potent, non-selective AR antagonists, several groups tried to modify the xanthine scaffold to obtain more potent and selective compounds. N7-methylation, as in caffeine, combined with coplanar aromatic substitution at the C8-position of xanthines as in the styrylxanthines 3 and 4 (Figure 1) led to high affinity and selectivity for the $A_{2 A} A R$ [6-8]. A disadvantage of the styrylxanthine structure is its photosensitivity in solid form as well as in dilute solutions [9]. 
First generation: Natural, nonselective adenosine receptor antagonists<smiles>Cn1c(=O)c2ncn(C)c2n(C)c1=O</smiles>

Caffeine 1<smiles>CN1C(=O)C2NC=NC2N(C)C1=O</smiles>

Theophylline

Second generation: 8-styrylxanthines - selective but photosensitive $A_{2 A} A R$ antagonists<smiles>C#CCn1c(=O)c2c(nc(/C=C/c3cccc(OC)c3)n2C)n(CCCO)c1=O</smiles>

MSX-2<smiles>CCn1c(=O)c2c(nc(/C=C/c3ccc(OC)c(OC)c3)n2C)n(CC)c1=O</smiles>

Istradefylline

Third generation: Selective $A_{2 A} A R$ antagonist 6 showing increased stability, obtained by cyclization of amide precursor 5<smiles>C#CCn1c(=O)[nH]c(N)c(NC(=O)C#Cc2ccccc2)c1=O</smiles>

5<smiles>C#CCn1c(=O)c2c(nc(C#Cc3ccccc3)n2C)n(C)c1=O</smiles>

6

Figure 1. Examples of adenosine receptor antagonists with a xanthine scaffold. Shown is the development of the xanthine derivatives caffeine and theophylline towards potent and selective adenosine $\mathrm{A}_{2 \mathrm{~A}}$ receptor antagonists.

Replacement of the styryl moiety present in $\mathbf{3}$ and $\mathbf{4}$, by an arylethynyl residue, as in $\mathbf{6}$, resulted in a new class of photochemically stable $\mathrm{A}_{2 \mathrm{~A}} \mathrm{AR}$ antagonists (Figure 1) [10]. Their 6-amino-5carboxamidouracil precursors (e.g., compound 5, Figure 1) were often not fully characterized, but directly converted to the final xanthine derivatives [11]. Upon close examination of ${ }^{1} \mathrm{H}-$ and ${ }^{13}$ C-NMR spectra of 6-amino-5-arylethynylcarboxamidouracil 8a (Scheme 1), obtained by coupling of 5,6-diamino-3-ethyl uracil 7 with phenylethynyl carboxylic acid, we observed a duplication of almost all signals (see Figure 2). However, this phenomenon was not observed for its styryl analog containing a double bond instead of the triple bond in 8a. Thus, we performed a comprehensive analytical study of 6-amino-5-arylethynylcarboxamidouracil (8a) in order to rationalize these unexpected observations. Additionally, different N1,N3-substituted 6-amino-5-carboxamidouracil derivatives were synthesized and analyzed. 
A<smiles>[R]OC(=O)OCC(=O)OCC(=O)O</smiles>

B<smiles>CCn1c(=O)[nH]c(N)c(N=CO)c1=O</smiles>

$8 b$<smiles>[R]C(O)Nc1c(N)[nH]c(=O)n(CC)c1=O</smiles>

$8 a$<smiles>[R]C(=O)Nc1[nH]c(=O)n(CC)c(=O)c1N</smiles>

9
C<smiles>CCNc1c(N)[nH]c(=O)n(CC)c1=O</smiles>

$8 a$

trans-amide<smiles></smiles>

$8 a$<smiles>[R]C(C)Nc1c(N)[nH]c(=O)n(CC)c1=O</smiles>

8c

Scheme 1. Potential products obtained by coupling of 5,6-diamino-3-ethyluracil 7 with phenylethynylcarboxylic acid. (A) Possible regioisomers $8 \mathbf{a}$ and $\mathbf{9}$ that could result from an amide coupling reaction of $\mathbf{7}$ with phenylethynylcarboxylic acid. (B) Possible formation of tautomers $\mathbf{8 b}, \mathbf{8 c}$, and $8 \mathbf{d}$ of $8 \mathbf{a}$. (C) Possible cis- and trans-amide bond conformers $8 \mathbf{a}$ and $8 \mathbf{e}$.
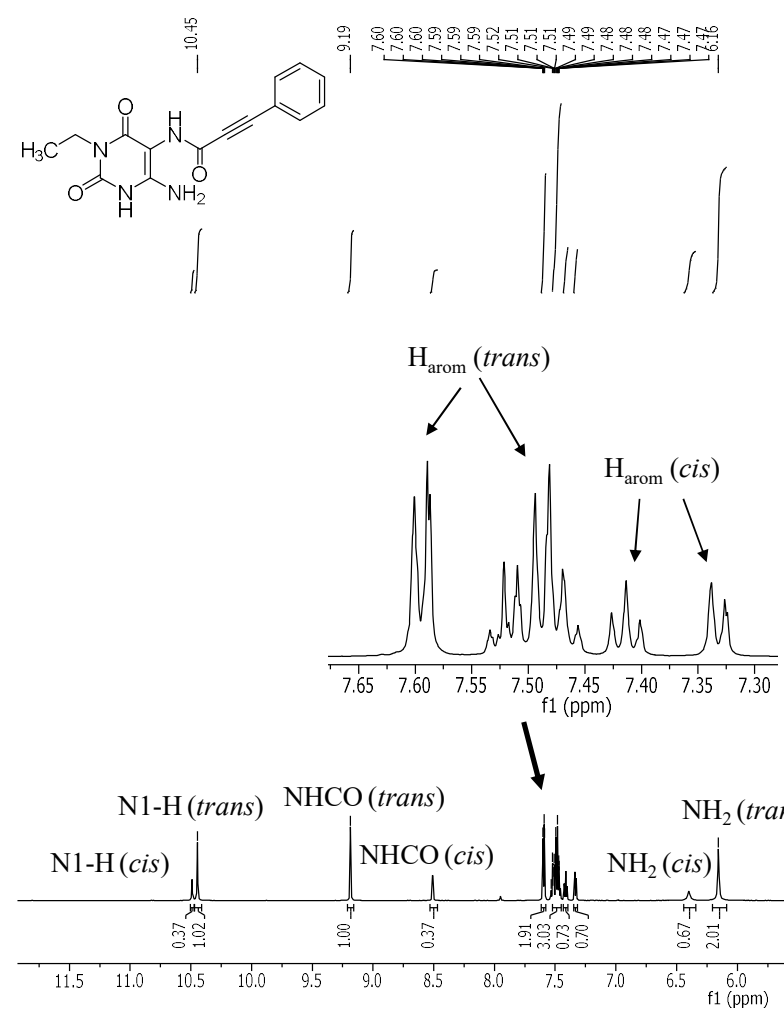

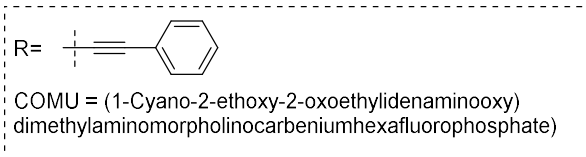

DIPEA = N,N-Diisopropylethylamine

Figure 2. ${ }^{1} \mathrm{H}-\mathrm{NMR}$ spectra of compound 8a in DMSO- $d_{6}$.

Different explanations for the duplication of peaks in the NMR spectra of 6-amino-5-arylethynylcarboxamides are conceivable. A mixture of regioisomers $8 \mathbf{a}$ and $\mathbf{9}$ appeared to be likely due to possible amide coupling with the 5- or the 6-amino group of 5,6-diamino-3-ethyluracil (7, Scheme 1A). On the other hand, the presence of amide-iminol tautomers might be possible (Scheme 1B, 
structures 8a, 8b, 8c, and 8d). Moreover, amides can exist as different stereoisomers with s-cis (cisoid) or s-trans (transoid) conformation (see Scheme 1C), a phenomenon that is well known for peptides [12-16].

In the present study, we performed dynamic and 2D-NMR studies and X-ray crystallography, and additionally employed computational methods to elucidate the structures of 5/6-amino-5/6carboxamidouracil derivatives such as 8/9 (Scheme 1). Different analogs of compound 8a were synthesized and analyzed in detail in order to explore if different N1,N3-substituents or different linkers affect the structures leading to a duplication of NMR signals, as observed for compound $\mathbf{8}$.

\section{Results and Discussion}

\subsection{Chemistry}

Condensation of 5,6-diaminouracil derivatives 7, 10, and 11 with different carboxylic acid derivatives in the presence of (1-cyano-2-ethoxy-2-oxoethylidenaminooxy)dimethylaminomorpholinocarbenium hexafluorophosphate (COMU) yielded the desired 6-amino-5-carboxamido derivatives $\mathbf{8}$ and 12-17 (Scheme 2). The amide coupling reaction was performed by the recently described optimized procedure using COMU as a coupling reagent in the presence of diisopropylethylamine (DIPEA) as a base in dimethylformamide (DMF) at room temperature [17]. The products were precipitated by the addition of water, filtered off, and dried; no further purification was required. These precursors can be further converted to the corresponding xanthine derivatives by a dehydrative cyclization reaction $[9,18,19]$.

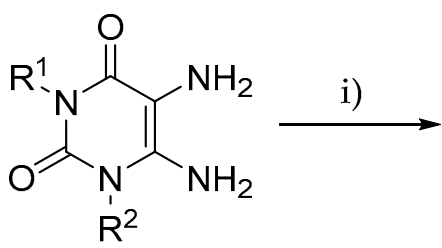

$$
\begin{aligned}
& 7: R^{1}=\text { Et, } R^{2}=H \\
& 10: R^{1}=\text { Propargyl, } R^{2}=H \\
& 11: R^{1}=M e, R^{2}=M e
\end{aligned}
$$

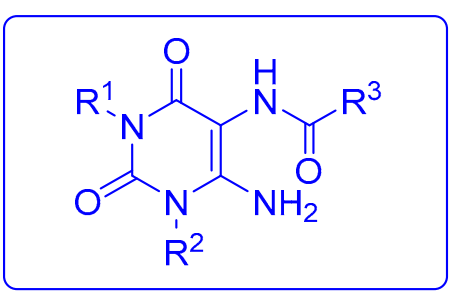

8a,12-17

For $\mathrm{R}^{3}$ see Table 1

Scheme 2. Synthesis of 6-amino-5-carboxamidouracil derivatives. Reagents and conditions: (i) $\mathrm{R}^{3}-\mathrm{COOH}, \mathrm{COMU}, \mathrm{DIPEA}, \mathrm{DMF}, \mathrm{rt}, 5 \mathrm{~min}, \mathrm{H}_{2} \mathrm{O}(79 \%-90 \%)$. The synthesis of the starting material was performed according to procedures described in the literature (Scheme S1 and S2, Supplementary Information) [9].

\subsection{Analytical Studies}

In order to explain the duplication of signals in the NMR spectra of compound 8a (Figure 2) different analytical experiments were performed. Yang et al. [20] described the formation of two regioisomers during the condensation reaction of 5,6-diamino-1,3-dimethyluracil with 2-hydroxyacetic acid. Furthermore, Poulsen et al. [21] proposed the formation of a 6-carboxamidouracil derivative during the condensation reaction of 5,6-diamino-1,3-dimethyluracil with glutamic anhydride. However, unambiguous evidence for the acylation of the 6-amino group was not provided by these authors.

High performance liquid chromatography (HPLC) of $\mathbf{8 a}$ pointed to only a single product, a first indication that different regioisomers were likely not present, and the formation of 9 could be excluded (Scheme 1A). Additionally, compound 12 was selected for dynamic HPLC (DHPLC) experiments to explore the compound's behavior at different temperatures. DHPLC measurements were performed at $5,15,25$, and $40^{\circ} \mathrm{C}$, but in all cases one single peak was observed. Only a slight shift in the retention times and peak broadening was visible upon decreasing of the temperature (Figure S16, Supporting Information). To further elucidate whether regioisomers, tautomers, or conformational isomers were 
responsible for the signal duplication in the NMR spectra, dynamic NMR and 2D-NMR experiments were performed.

\subsubsection{Dynamic NMR Experiments of 8a at High Temperatures}

The most deshielded signal, that of the $\mathrm{N1}-\mathrm{H}$, resonates as a broad singlet at 10.43 ppm measured in DMSO- $d_{6}$, and the second signal of the corresponding isomer is slightly shifted downfield to $10.48 \mathrm{ppm}$. The amide proton resonates at $9.17 \mathrm{ppm}$ as a broad singlet, and the second signal shows a large upfield shift to $8.50 \mathrm{ppm}$. The amino group at position six resonates as a broad singlet at $6.14 \mathrm{ppm}$ with an integration of two, while the corresponding second signal is shifted downfield to $6.39 \mathrm{ppm}$, showing an integration of 0.67. Dynamic NMR experiments were performed to study whether different tautomers of 8a were present. The temperature should have a measurable influence on the ratio between tautomers. At a higher temperature, a higher percentage of the thermodynamically more stable tautomer would be expected [22]. ${ }^{1} \mathrm{H}$ - and ${ }^{13} \mathrm{C}-\mathrm{NMR}$ spectra were recorded in DMF- $d_{7}$ and DMSO- $d_{6}$ from 223 to $378 \mathrm{~K}$ with $5-10 \mathrm{~K}$ intervals. The ratio of the isomers determined by integration of the ${ }^{1} \mathrm{H}-\mathrm{NMR}$ signals was found to be 73:27. Unexpectedly, in both solvents, no change in the ratio between the two species could be observed upon raising of the temperature (Figure 3 ). Since the dynamic NMR experiments showed that the existence of two tautomers next to each other in solution could be excluded (Scheme 1B), a third explanation was investigated in more detail. To confirm the third hypothesis of different conformers, 2D-NMR experiments in DMSO- $d_{6}$ and DMF- $d_{7}$ were performed.

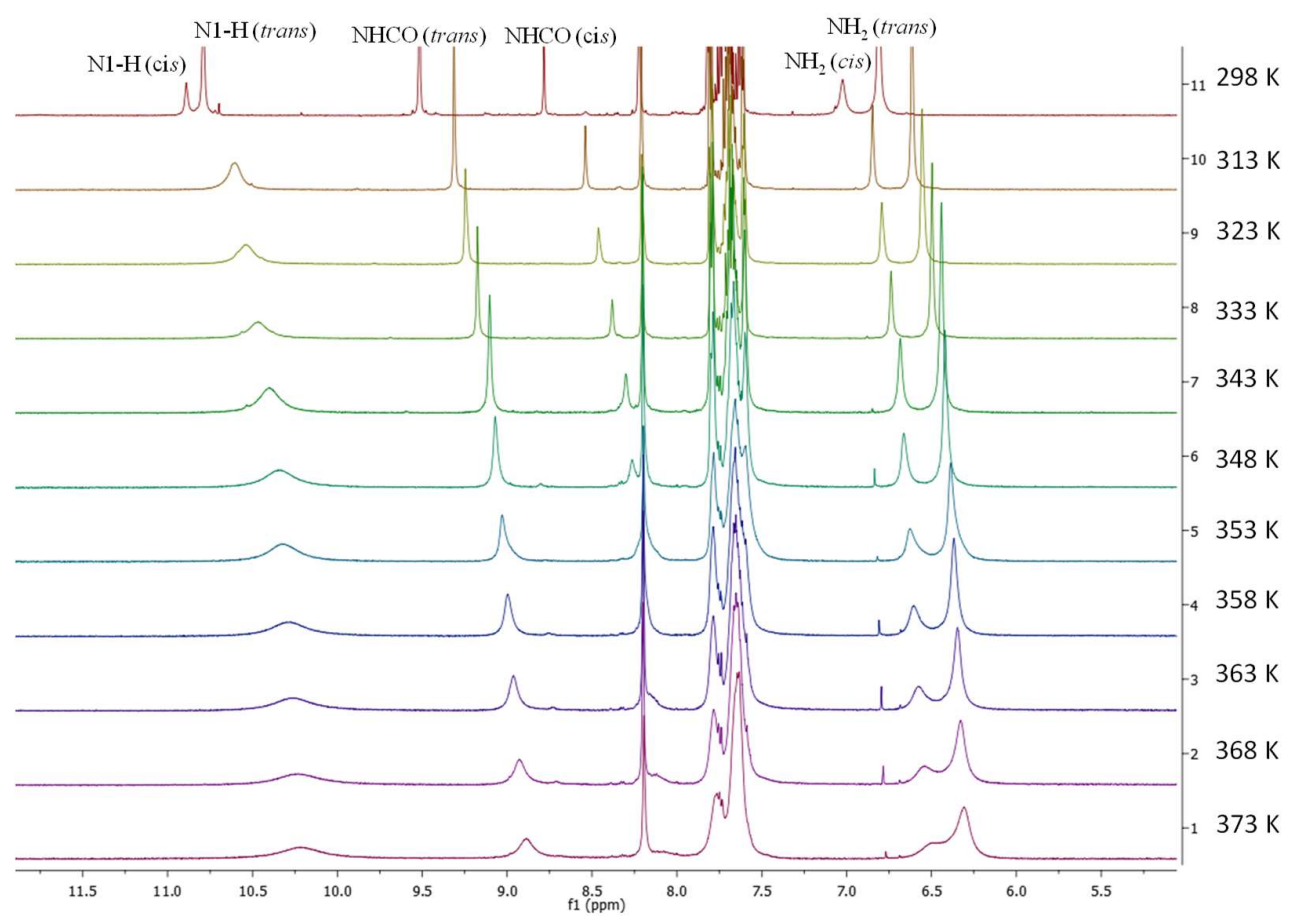

Figure 3. Dynamic NMR experiments of carboxamidouracil 8a at high temperatures. The ${ }^{1} \mathrm{H}-\mathrm{NMR}$ spectra from 5.0 to $12.0 \mathrm{ppm}$ of $8 \mathrm{a}$ were measured in DMSO- $d_{6}$ at different temperatures, between 298 and $373 \mathrm{~K}$, to analyze the signals of the 6-amino group, the amide $\mathrm{NH}$, and the N1-H in detail.

\subsubsection{Two-Dimensional NMR Studies}

Nuclear Overhauser enhancement and exchange spectroscopy (NOESY and EXSY) experiments, showed the presence of cross peaks with the same phase as the diagonal peaks (experimental mixing time D8 of $300 \mathrm{~ms}$, Figure 4) for almost all ${ }^{1} \mathrm{H}$ signals, which points to a chemical exchange mechanism [12,23]. This takes place if a nucleus is transferred from one magnetic environment to another. As an example, the EXSY cross peaks of the cis-amide NH at $8.50 \mathrm{ppm}$ and the trans-amide $\mathrm{NH}$ at 9.20 ppm are shown in Figure 4 in the same sign of the diagonal peaks (shown in red). Chemical 
exchange with the solvent could be excluded by the fact that we observed a cross-correlation also for non-exchangeable protons. Cross-correlation in phase of the signal of one conformer with the corresponding signal from the other conformer was observed as a proof for conformer equilibrium (Figure 4).

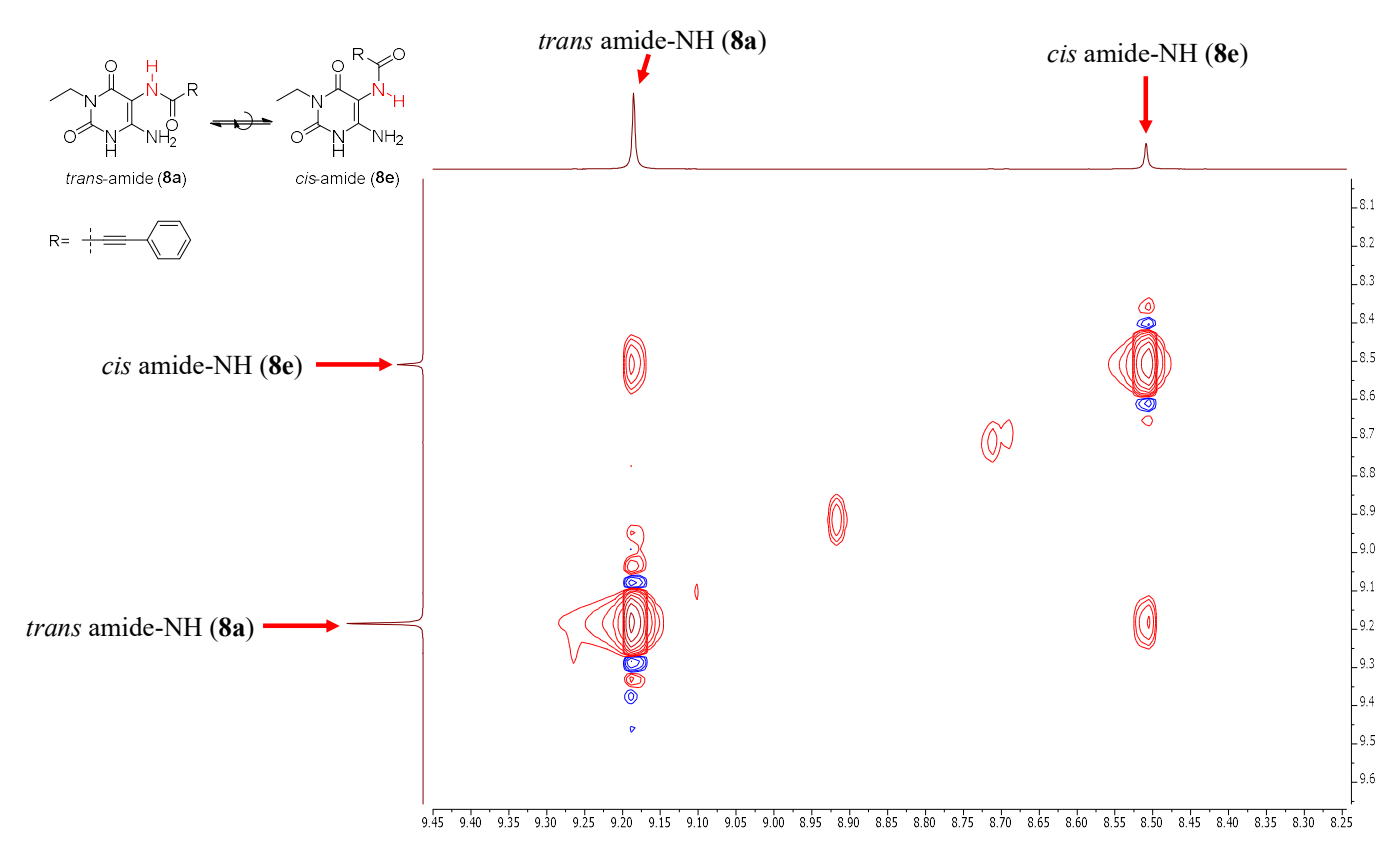

Figure 4. Exchange spectroscopy (EXSY)-NMR spectrum of 8a in DMSO- $d_{6}$ indicating cross-correlation in phase between the two amide-NH protons of conformer 8a and 8e. EXSY cross peaks of the cis-amide $\mathrm{NH}$ at $8.50 \mathrm{ppm}$ and the trans-amide $\mathrm{NH}$ at $9.20 \mathrm{ppm}$ are shown.

These results clearly showed that the duplication of peaks in the NMR spectra of $\mathbf{8 a}$ (and related amidouracil derivatives) was due to the presence of different conformational isomers, such as $\mathbf{8 a}$ and 8e (Scheme 1C).

\subsubsection{Analysis of Differently Substituted 5-Amino-6-Carboxamidouracil Derivatives}

We subsequently synthesized and investigated different 6-amino-5-carboxamidouracil derivatives with various carboxylic acid residues (Table 1) by dynamic and multidimensional NMR experiments. The equilibrium of their conformers and the energy of their rotational barrier were analyzed. In order to explore if the N1-substitution or the N3-substitution has any influence on the conformer equilibrium, compounds 12 (3-propargyl) and 13 (1,3-dimethyl) were synthesized (Table 1). Neither the change of the substitution pattern at the N1- or N3-position nor diethoxy substitution at the phenylethynyl residue changed the cis-trans ratio significantly (Table 1 ; compare $\mathbf{8 a}, \mathbf{1 2}$, and $\mathbf{1 3}$ ). 
Table 1. Synthesized 6-amino-5-carboxamidouracil derivatives, yields, and experimental trans/cis ratios from ${ }^{1} \mathrm{H}-\mathrm{NMR}$ in DMSO- $d_{6}$.

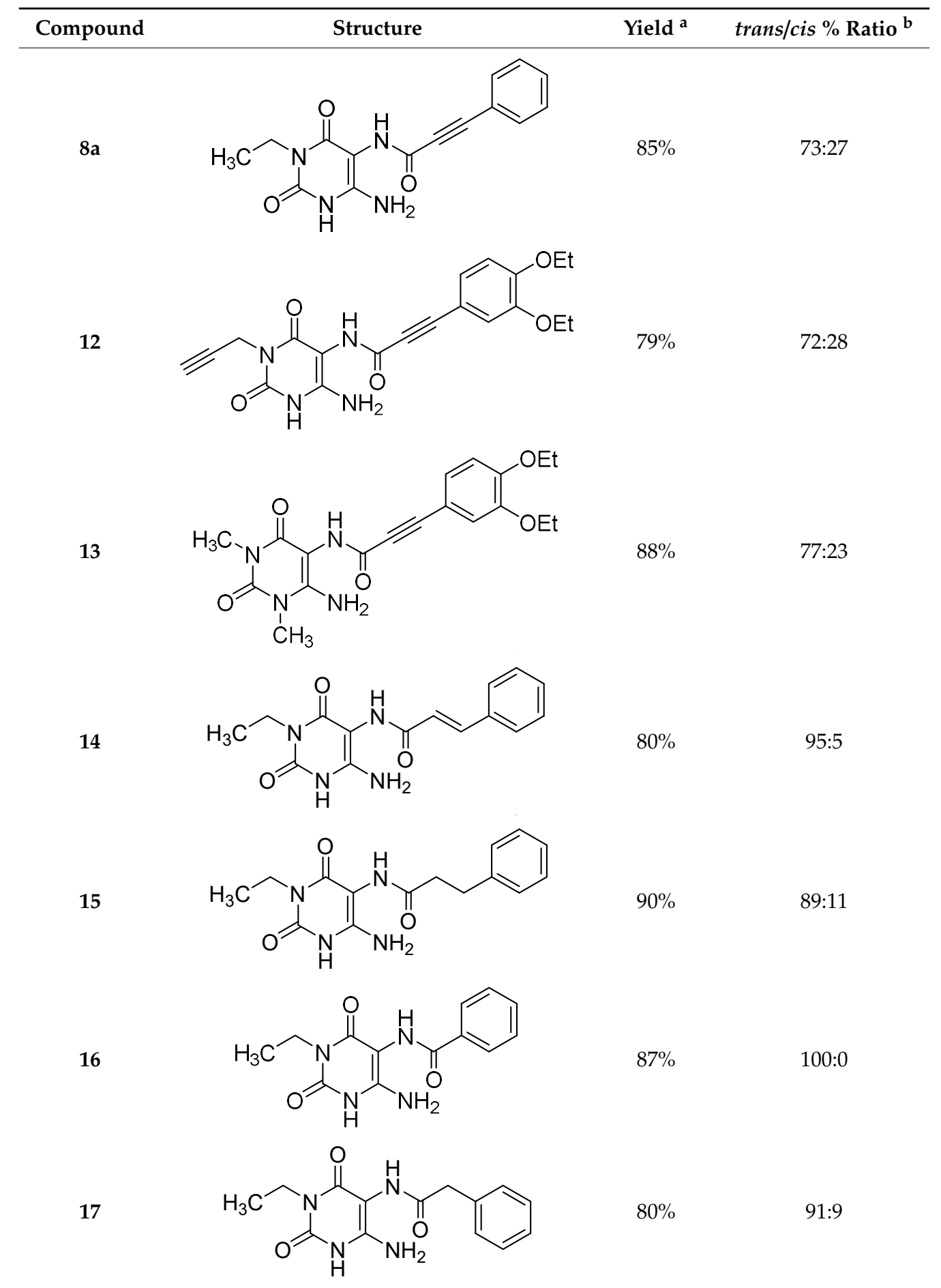

a Isolated yields of the amide coupling reaction of 5,6-diaminouracil derivatives $(7,10$, and 11) with different carboxylic acid derivatives. ${ }^{b}$ The ratio of the cis- and trans-amide conformers of $\mathbf{8 a}$ and $\mathbf{1 2}-\mathbf{1 7}$ were determined by integration of their ${ }^{1} \mathrm{H}-\mathrm{NMR}$ signals.

Finally, derivatives containing different linkers were prepared and analyzed. In the case of 8-arylethynyl derivatives the amount of the less stable conformer was between $20 \%$ and $30 \%$ in all three investigated cases (8a, $\mathbf{1 2}$, and $\mathbf{1 3}$ ). Mainly a single conformer was observed for the styryl-substituted derivative 14, while with a single-bond linker in phenylethyl derivative 15 the ratio of trans- and 
cis-amide was approximately 89:11. A shorter linker shifted the equilibrium to a single conformer (16, 17). However, this might also be due to a fast equilibrium between these two isomers, which cannot be distinguished by NMR spectroscopy. Due to the crystal structure and density functional theory (DFT) calculation of compound 8a and the NOESY spectra of compound 17, the trans-amide conformer is concluded to be the more stable rotational conformer.

\subsubsection{NMR Studies at Low Temperature}

When further dynamic NMR experiments were performed for amide 8 at low temperature (213-283 K), a different conformer equilibrium was observed. NOESY spectra at $223 \mathrm{~K}$ showed the separation of the amino groups of both amide conformers 8a and 8e (Figure 5). A cross-correlation for the amino group of conformer A (compound 8a) was found between two peaks at 6.76 and $7.89 \mathrm{ppm}$. The same cross peak was found for the amino group of conformer B (compound 8e) at 6.58 and $7.58 \mathrm{ppm}$. The peak corresponding to the amino group of conformer B could only be observed with NOESY NMR because it was covered by the aromatic signals. The latter was expected to slow rotation of the $\mathrm{Csp}^{2}-\mathrm{N}$ bond [24]. The coalescence temperature of this amino group could be observed between 228 and $233 \mathrm{~K}$ (Figure 6). Using the simplified Eyring equation (Equation (4)), compound 8a showed a rotational barrier for the amino group, $\Delta \mathrm{G}^{\#}=46.4 \pm 0.42 \mathrm{~kJ} \cdot \mathrm{mol}^{-1}$.

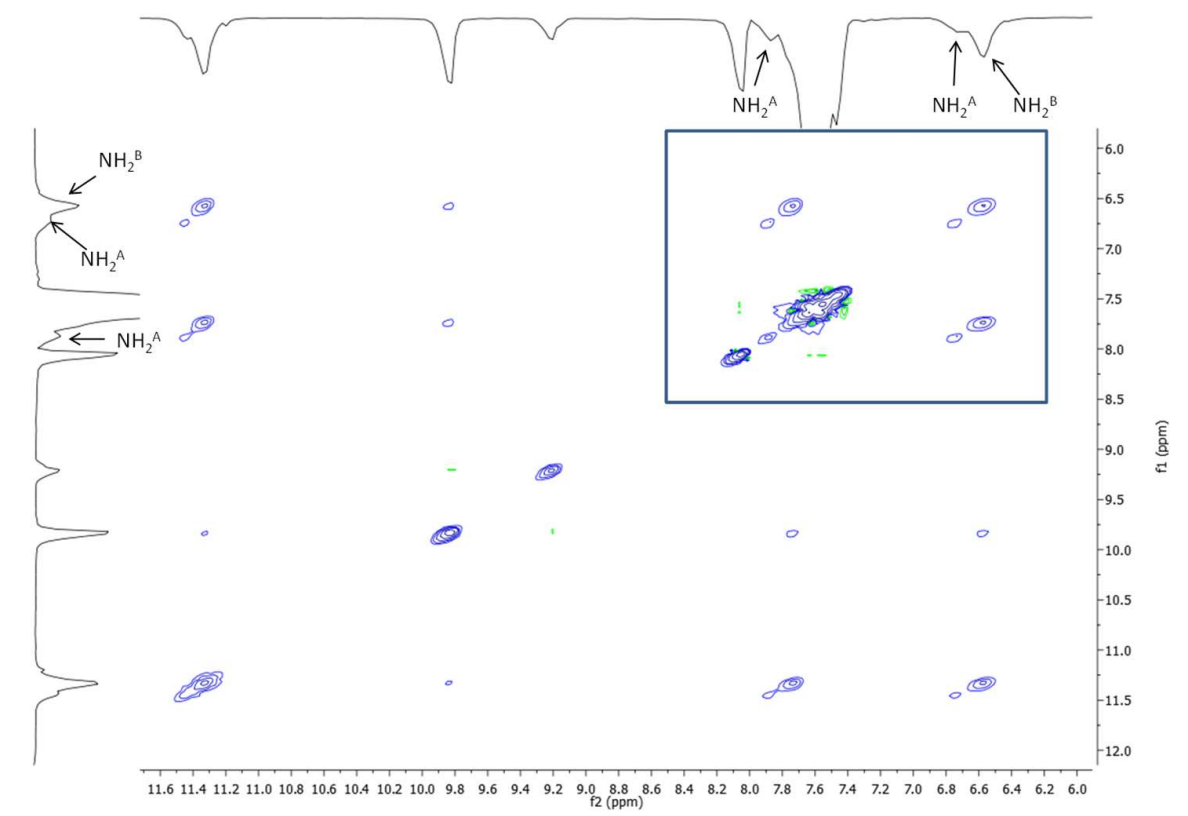

Figure 5. EXSY cross-correlation in DMSO- $d_{6}$ suggesting a low rotational barrier of the $\mathrm{C}_{\mathrm{sp}}{ }^{2}-\mathrm{N}$ bond in amide $\mathbf{8} \mathbf{a}$ and $\mathbf{8 e}$. Cross-correlations for the amino groups of conformer $\mathrm{A}$ and conformer $\mathrm{B}$ were found at 6.76 and $7.89 \mathrm{ppm}$, and at 6.58 and $7.58 \mathrm{ppm}$, respectively. 


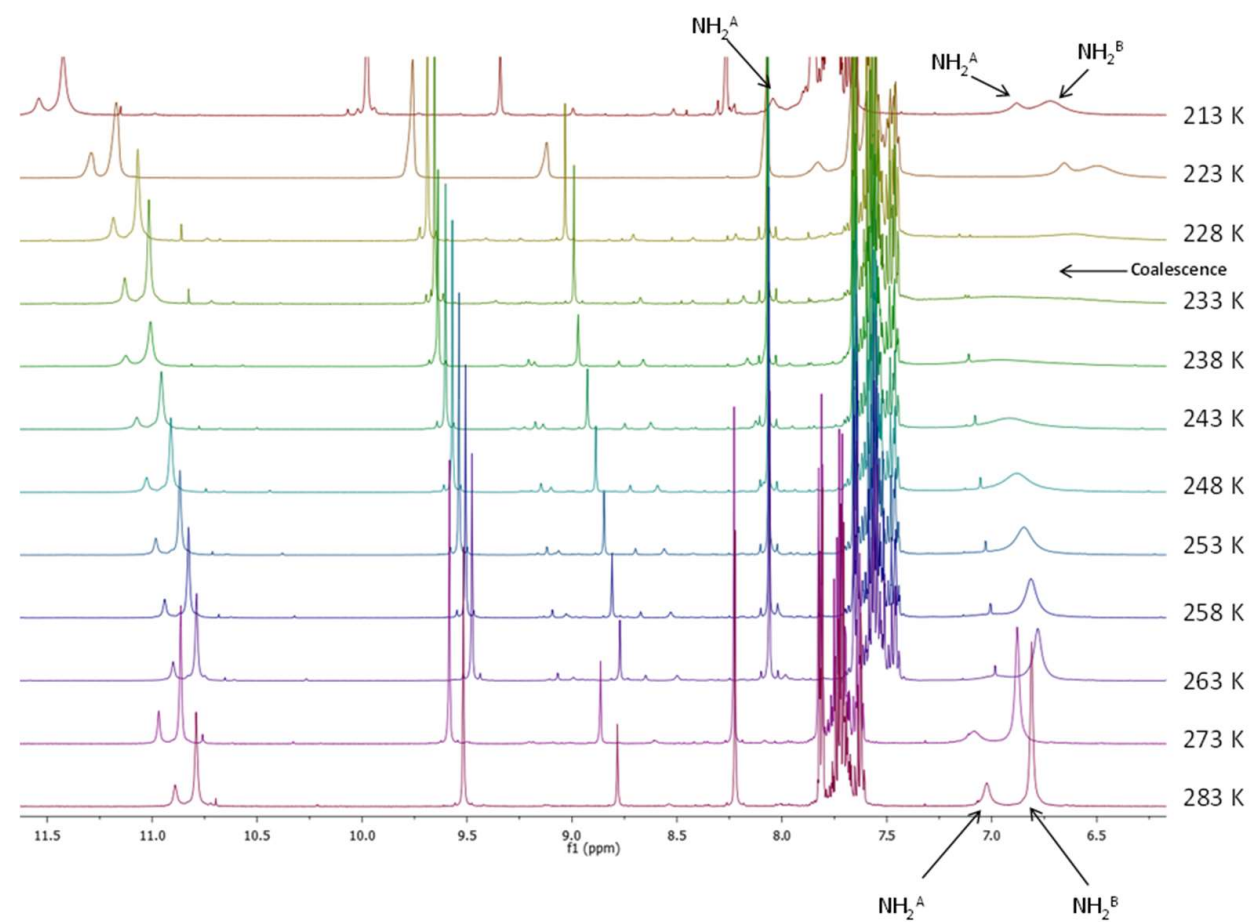

Figure 6. Proton dynamic NMR experiments of the carboxamidouracil isomers $8 \mathbf{a}$ and $8 \mathbf{e}$ in DMF- $d_{7}$ at low temperature. Different NMR spectra for amide 8 were recorded from 213-283 K, with 5-10 K intervals. Coalescence of the 6-amino group was detected between $228 \mathrm{~K}$ and $233 \mathrm{~K}$.

However, the Eyring equation to calculate $\Delta \mathrm{G}^{\#}$ can only be used if the thermodynamic stability of the two conformers is equal. To determine $\Delta \mathrm{G}^{\#}$, quantum chemical calculations are required. A line-shape analysis was not possible due to the fact that the coalescence temperature was above $105^{\circ} \mathrm{C}$ (see Figure 3). In order to predict the 3D structures of these conformers, density functional theory (DFT) calculations in liquid phase and X-ray crystallography for the solid state of 8a were subsequently performed (Figures 7 and 8 ).

\subsubsection{DFT Calculations}

The DFT computed free energy difference between the two conformers is $\Delta \mathrm{G}^{\#}=-1 \mathrm{kcal}$, which corresponds to a $\mathrm{k}_{\text {trans }} / \mathrm{k}_{\mathrm{cis}}$ ratio of 84:16 (Figure 7) at room temperature. This is consonant with the NMR results, which showed a ratio of 73:27 both indicating a higher stability of the s-trans conformer. The rotational barrier in DMSO solution is calculated to be $\Delta \mathrm{G} \#=20.0 \mathrm{kcal} \cdot \mathrm{mol}^{-1}$, which is in accordance with the results from the NMR experiments.

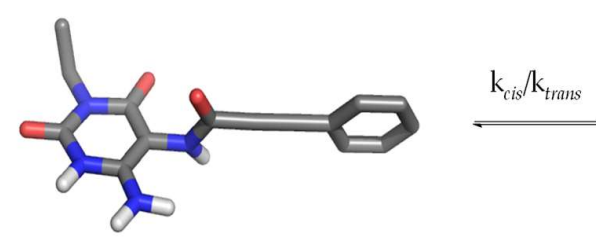

Geometry-optimized s-trans conformer

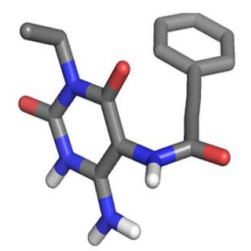

Geometry-optimized s-cis conformer

Figure 7. Geometry-optimized amide bond rotational conformers $8 \mathbf{a}$ and $\mathbf{8 e}$. The conformers are shown in stick models (carbon atoms colored grey, oxygen atoms in red, the nitrogen atoms in blue, and the hydrogen atoms connected to nitrogen in white). 


\subsubsection{X-ray Crystal Structure}

Several solvents were tried to obtain single crystals, but finally we only obtained suitable crystals (triclinic space group P1) of compound 8a from DMSO solution. The resulting crystal structure showed exclusively the more stable regioisomer $8 \mathbf{a}$ (Figure 8). No intramolecular hydrogen bonding and no $\pi$-stacking between the molecules was observed. The crystals were found to be mainly formed by intermolecular hydrogen bonding as shown in Figure 8.

A

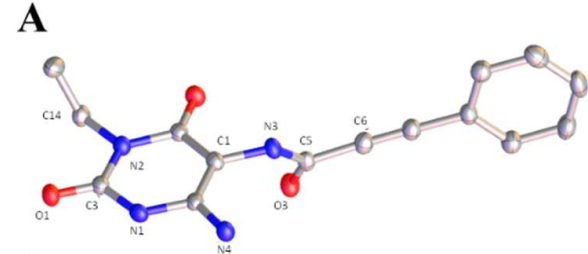

C

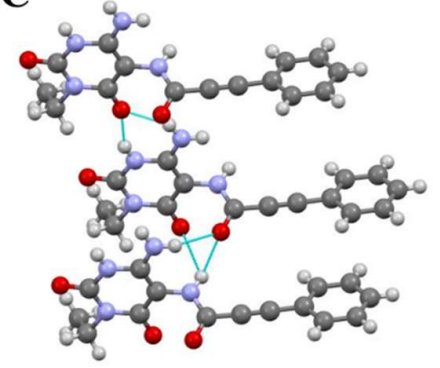

$\mathbf{E}$

\begin{tabular}{|c|c|c|c|c|}
\hline $\mathbf{D}$ & $\mathbf{H}$ & $\mathbf{A}$ & $\mathbf{d}(\mathbf{D}-\mathbf{A}) / \hat{\mathbf{A}}$ & $\mathbf{D}-\mathbf{H}-\mathbf{A} /{ }^{\circ}$ \\
\hline N1 & $\mathrm{H} 1$ & $\mathrm{O} 2^{1}$ & $2.721(3)$ & 154.8 \\
\hline N3 & $\mathrm{H} 3$ & $\mathrm{O} 3^{2}$ & $2.911(2)$ & 125.6 \\
\hline N4 & $\mathrm{H} 4 \mathrm{~A}$ & $\mathrm{O} 2^{1}$ & $2.879(2)$ & 144.0 \\
\hline N4 & $\mathrm{H} 4 \mathrm{~B}$ & $\mathrm{O} 3^{2}$ & $2.955(2)$ & 149.2 \\
\hline C15 & $\mathrm{H} 15 \mathrm{~A}$ & $\mathrm{O}^{3}$ & $3.288(3)$ & 171.5 \\
\hline
\end{tabular}

B<smiles>CCn1c(=O)[nH]c(N)c(NC(=O)C#Cc2ccccc2)c1=O</smiles>

D

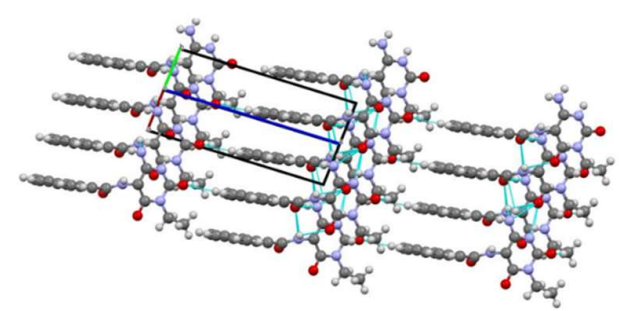

Figure 8. Results of the single X-ray crystallography of compound 8. X-ray crystal structure (A) and chemical structure (B) of compound 8a. (C) Intermolecular hydrogen bond interactions in the crystal (colored in cyan). (D) Crystal unit cell of the P1 space group. (E) Distances of intermolecular interactions in the crystal structure. For color coding see Figure 7.

\section{Conclusions}

6-Amino-5-carboxamidouracil derivatives, which are important intermediates in the synthesis of pharmaceutically important 8-substituted xanthine derivatives, were observed to show a more or less pronounced duplication of NMR signals, depending on their carboxylic acid residue. In order to understand this phenomenon, selected 6-amino-5-carboxamidouracils were analyzed using dynamic and 2D NMR-experiments, DFT calculations, and single-molecule X-ray crystallography. The duplication of NMR signals could be correlated with a partial double bond character of the amide bond and a low rotational barrier of this bond depending on the carboxylic acid residue. According to DFT calculations, in the case of 5-ethynylcarboxamidouracils, the triple bond appears to stabilize the thermodynamically less stable cis conformer. This could be observed in solution, while the obtained crystal structure consisted solely of the more stable trans conformer. 


\section{Materials and Methods}

Chemicals were purchased from Merck (Darmstadt, Germany), ABCR (Karlsruhe, Germany), or TCI (Eschborn, Germany). Thin layer chromatography (TLC) was performed on TLC plates $\mathrm{F}_{254}$ (Merck) and analyzed using UV light. High-resolution mass spectra (HR-MS) were recorded on a micrOTOF-Q mass spectrometer (Bruker, Billerica, MA, USA), further mass spectra were performed on an API 2000 (Applied Biosystems, Foster City, CA, USA) mass spectrometer. ${ }^{1} \mathrm{H}$ - and ${ }^{13} \mathrm{C}-\mathrm{NMR}$ spectra were recorded in $\mathrm{CDCl}_{3}, \mathrm{DMSO}-d_{6}$, or DMF- $d_{7}$ on a Bruker Ascend $600 \mathrm{MHz}$ NMR-spectrometer (Bruker) operating at $600.18 \mathrm{MHz}\left({ }^{1} \mathrm{H}\right)$ or $150.93 \mathrm{MHz}\left({ }^{13} \mathrm{C}\right)$, respectively. Chemical shifts $(\delta)$ are reported in ppm and are referenced to the chemical shifts of the residual solvent proton(s) present in $\mathrm{CHCl}_{3}$ (7.26 ppm for the ${ }^{1} \mathrm{H}-\mathrm{NMR}$ spectra and $77.16 \mathrm{ppm}$ for the ${ }^{13} \mathrm{C}-\mathrm{NMR}$ spectra), in DMSO (2.50 ppm for the ${ }^{1} \mathrm{H}-\mathrm{NMR}$ spectra and $39.52 \mathrm{ppm}$ for the ${ }^{13} \mathrm{C}-\mathrm{NMR}$ spectra), and in DMF (2.75 ppm for the ${ }^{1} \mathrm{H}-\mathrm{NMR}$ spectra and $29.76 \mathrm{ppm}$ for the ${ }^{13} \mathrm{C}-\mathrm{NMR}$ spectra). Multiplicity: s, singlet; $\mathrm{d}$, doublet; q, quartet; $\mathrm{m}$, multiplet. Coupling constants $(J)$ are shown in Hertz $(\mathrm{Hz})$. Dynamic HPLC analyses were performed on "Knauer GmbH" (Berlin, Germany) systems of the "PLATINblue" series with a P-1 pump, a column oven, a PDA-1 diode array UV-detector, and a Knauer Eurospher II 100-2 C18, (2 mm, $100 \times 2.0 \mathrm{~mm}$; number 19040303147) column. The solvents were of HPLC grade.

\subsection{Eyring Equation}

If rotation around an amide bond is slow on the NMR timescale, and the rotational barrier is between 3 and $19 \mathrm{kcal} / \mathrm{mol}$, the observation of two conformers is permitted due to the partial double bond character of the amide $\mathrm{C}-\mathrm{N}$ bond [25]. Under this assumption, one sharp peak for the duplicated signals of $\mathbf{8}$ should be observed at the coalescence temperature in the ${ }^{1} \mathrm{H}-\mathrm{NMR}$ spectrum [12,26-28]. Thus, the rotational barrier could be determined using the Eyring equations. Before the coalescence temperature is reached, the interconversion rate constant corresponds to the following equation:

$$
\mathrm{k}=\frac{1}{\mathrm{t}} \ll \pi \frac{\Delta v}{\sqrt{2}}
$$

where $\mathrm{k}$ is interconversion rate constant $\left(\mathrm{s}^{-1}\right), t$ is interconversion time (s), and $\Delta v$ is the NMR shift $(\mathrm{Hz})$ separation of the signals at low temperatures when exchange does not occur.

Heating leads to a faster exchange rate relative to the NMR timescale and only one averaged signal becomes detectable. At the coalescence temperature, the equation of the interconversion rate constant is

$$
\mathrm{k}_{\mathrm{Tc}}=\pi \frac{\Delta v}{\sqrt{2}}
$$

where $\mathrm{k}_{\mathrm{Tc}}$ is the rate constant $\left(\mathrm{s}^{-1}\right)$.

The free Gibbs activation energy $\Delta \mathrm{G} \#$ of rotation can be calculated using the following Eyring equations:

$$
\begin{gathered}
-\Delta \mathrm{G}^{\#}=\mathrm{K} \frac{\mathrm{k}_{\mathrm{B}} \times \mathrm{T}}{\mathrm{h}} \mathrm{e}^{\frac{-\Delta \mathrm{G}^{\#}}{\mathrm{RT}}} \\
\Delta \mathrm{G}^{\#}=4.57 \times 10^{-3} \mathrm{~T}\left(9.972+\log \frac{\mathrm{Tc}}{\Delta v}\right)
\end{gathered}
$$

where $\mathrm{R}$ is the universal gas constant $\left(\frac{1.0872 \mathrm{cal}}{\mathrm{K} \cdot \mathrm{mol}}\right), k_{B}$ is the Boltzmann constant $\left(3.2998 \times 10^{-24} \frac{\mathrm{cal}}{\mathrm{K}}\right), \mathrm{h}$ is the Planck constant $\left(1.584 \times 10^{-34} \mathrm{cal} \cdot \mathrm{s}\right)$, and $\mathrm{T}_{\mathrm{C}}$ is the coalescence temperature $(\mathrm{K})$ [12].

\subsection{DFT Calculation}

Most of the quantum chemical calculations were carried out with the TURBOMOLE and ORCA programs $[29,30]$. All structures were fully optimized at the dispersion-corrected DFT level using the PBEh-3c DFT [31]. This composite method contains a modified Perdew-Burke-Ernzerhof (PBE)-based hybrid function together with an efficient valence double-zeta AO basis set. The method also involves 
an approximate counterpoise correction for basis set superposition errors (BSSE), as well as three-body dispersion effects [31]. Conformational searches [32], pre-optimizations, as well as the calculation of the Hessian to start transition state searches were conducted at the semi-empirical tight-binding level (GFN-xTB method) [33]. The GFN-xTB-optimized structures were used as input for subsequent full PBEh-3c optimizations. Reaction paths were obtained with the growing-string method (GSM) of Zimmerman [34] which was interfaced to our in-house XTB code [35]. Single-point gas phase energies were computed with the large polarized triple-zeta (def2-TZVPP) sets by Weigend et al. [36] in combination with the very accurate DSD-BLYP double hybrid functional [37]. The atom pairwise D3 correction with Becke-Johnson (BJ) damping to account for intra- and intermolecular London dispersion interactions was included in all treatments [38]. Note, that the original D2 treatment in DSD-BLYP is replaced by the D3 version (with damping parameters $s 6=0.57, \mathrm{a} 1=0, \mathrm{~s} 8=0$, $\mathrm{a} 2=5.4$ ) [39]. This functional performs excellently on the huge GMTKN55 thermochemical database (i.e., is practically the best out of 200+ tested DFT approximations) [40]. The combined level of theory used for electronic gas phase energies is denoted DSD-BLYP/TZ//PBEh-3c in standard notation. In all DFT treatments, the resolution-of-the-identity approximation [41] has been used for the two-electron integrals to speed up the computations. The numerical quadrature grid $\mathrm{m} 4$ (grid 5 in ORCA) was employed for the integration of the exchange-correlation contribution. Gibbs free energies at $298.15 \mathrm{~K}$ in DMSO were reported as a solvent (termed $\Delta \mathrm{G}$ ). The ro-vibrational corrections to the free energy are obtained from a modified rigid rotor, harmonic oscillator statistical treatment [42] based on scaled harmonic frequencies obtained at the (gas phase) HF-3c [43] level. For the entropy, all frequencies with wavenumbers below $100 \mathrm{~cm}^{-1}$ were treated as mixed rigid rotors and harmonic oscillators. Solvent effects on the thermochemical properties have been obtained by the COSMO-RS method [44] (COSMOtherm software package [44], parametrization from 2016) based on BP86/TZVP [36,45] single-point calculations. The PBEh-3c as well as GFN-xTB optimizations were run consistently in a continuum solvent. For GFN-xTB the built-in GBSA solvation model 23 is employed; while for PBEh-3c, the DCOSMO-RS method is used [46]. The solvation contributions to free energies at $298.15 \mathrm{~K}$ in DMSO solution are computed at those structures (i.e., PBEh-3c[DCOSMO-RS]) The computed free energies are obtained by $\Delta \mathrm{G}=\Delta \mathrm{E}+\Delta \mathrm{GRRHO}+\Delta \delta \mathrm{GCOSMO}-\mathrm{RS}$, where the last two terms refer to the above mentioned ro-vibrational/translational and solvation contributions, respectively, to the free energy. The final theory level is denoted as DSD-BLYP/TZ[COSMO-RS(BP86/TZVP)]/PBEh-3c[DCOSMO-RS] where the abbreviations in square brackets denote the level of the solvation treatment.

\subsection{General Procedures}

\subsubsection{Synthesis of 5,6-Diaminouracil Derivatives}

The different $\mathrm{N}$-substituted 5,6-diaminouracils where synthesized in analogy to procedures described in the literature [9].

\subsubsection{General Procedure for Amide Formation}

To a solution of the respective carboxylic acid (1.0 equiv.) and COMU (1.1 equiv.), dissolved in a minimum amount of DMF, a mixture of diaminouracil derivative (1.1 equiv.) and DIPEA (2.0 equiv.), dissolved in a minimum amount of DMF, was added dropwise. The reaction was stirred for 5-10 min at room temperature. Then, water was added, and the resulting precipitate was filtered off, washed with water, and dried under reduced pressure.

\subsubsection{NMR Spectra}

$\mathrm{N}$-(6-Amino-3-ethyl-2,4-dioxo-1,2,3,4-tetrahydropyrimidin-5-yl)-3-phenylpropiolamide (8). Yield: 85\% (white solid); $\mathrm{mp}=270-272{ }^{\circ} \mathrm{C}$. Major isomer: ${ }^{1} \mathrm{H}-\mathrm{NMR}\left(600 \mathrm{MHz}, \mathrm{DMSO}-d_{6}\right) \delta 10.45(\mathrm{~s}, 1 \mathrm{H}, \mathrm{N} 1-\mathrm{H})$, $9.16(\mathrm{~s}, 1 \mathrm{H}, \mathrm{CONH}), 7.62-7.56\left(\mathrm{~m}, 2 \mathrm{H}, \mathrm{H}_{\text {arom }}\right), 7.53-7.45\left(\mathrm{~m}, 3 \mathrm{H}, \mathrm{H}_{\text {arom }}\right), 6.14\left(\mathrm{~s}, 2 \mathrm{H}, \mathrm{NH}_{2}\right), 3.79-3.67$ $\left(\mathrm{m}, 2 \mathrm{H}, \mathrm{N} 1-\mathrm{CH}_{2}\right), 1.04\left(\mathrm{t}, J=7.0 \mathrm{~Hz}, 2 \mathrm{H}, \mathrm{CH}_{2} \mathrm{CH}_{3}\right) .{ }^{13} \mathrm{C}-\mathrm{NMR}\left(126 \mathrm{MHz}, \mathrm{DMSO}-d_{6}\right) \delta 160.0(\mathrm{CON})$, 
152.7 (C6), 150.2 (CO), 149.5 (CO), 132.0 (2C, $\left.\mathrm{C}_{\text {arom }}\right), 130.2$ (C arom $), 129.0$ (2C, $\left.\mathrm{C}_{\text {arom }}\right), 120.0$ (C $\left.\mathrm{C}_{\text {arom }}\right), 85.7$ (C5 or $\left.\mathrm{C}_{\text {alkyne }}\right), 84.9$ (C5 or $\left.\mathrm{C}_{\text {alkyne }}\right), 83.6$ (C5 or $\left.\mathrm{C}_{\text {alkyne }}\right), 34.4\left(\mathrm{~N} 1-\mathrm{CH}_{2}\right), 13.2\left(\mathrm{CH}_{2} \mathrm{CH}_{3}\right)$. Minor isomer: ${ }^{1} \mathrm{H}-\mathrm{NMR}\left(600 \mathrm{MHz}, \mathrm{DMSO}-d_{6}\right) \delta 10.49$ (s, 1H, N1-H), 8.51 (s, 1H, CONH), 7.54-7.51 (m, 1H, Harom), 7.43-7.39 (m, 2H, $\left.\mathrm{H}_{\text {arom }}\right), 7.35-7.32\left(\mathrm{~m}, 2 \mathrm{H}, \mathrm{H}_{\text {arom }}\right), 6.40\left(\mathrm{~s}, 2 \mathrm{H}, \mathrm{NH}_{2}\right), 3.74-3.78\left(\mathrm{~m}, 2 \mathrm{H}, \mathrm{N} 1-\mathrm{CH}_{2}\right), 1.01(\mathrm{t}$, $\left.J=7.0 \mathrm{~Hz}, 3 \mathrm{H}, \mathrm{CH}_{2} \underline{\mathrm{CH}}_{3}\right) .{ }^{13} \mathrm{C}-\mathrm{NMR}\left(151 \mathrm{MHz}, \mathrm{DMSO}-d_{6}\right) \delta 162.3$ (CON), $157.6(\mathrm{C} 6), 151.5$ (CO), 149.5 (CO), 132.0 (2C, $\left.\mathrm{C}_{\text {arom }}\right), 130.3$ ( $\left.\mathrm{C}_{\text {arom }}\right), 129.0$ (2C, $\left.\mathrm{C}_{\text {arom }}\right), 120.0$ ( $\left.\mathrm{C}_{\text {arom }}\right), 87.5$ (C5 or $\left.\mathrm{C}_{\text {alkyne }}\right), 85.8$ (C5 or C alkyne), $83.2\left(\mathrm{C} 5\right.$ or $\left.\mathrm{C}_{\text {alkyne }}\right), 34.4\left(\mathrm{~N} 1-\mathrm{CH}_{2}\right), 13.3\left(\mathrm{CH}_{2} \underline{\mathrm{CH}}_{3}\right)$. High resolution mass spectra (HRMS) (electrospray ionization-quadrupole-time-of-flight) (ESI-QTOF)) calculated for $\mathrm{C}_{15} \mathrm{H}_{14} \mathrm{~N}_{4} \mathrm{O}_{3}[\mathrm{M}+\mathrm{H}]^{+}$: 299.1139; found: 299.1139 .

N-(6-Amino-2,4-dioxo-3-(prop-2-yn-1-yl)-1,2,3,4-tetrahydropyrimidin-5-yl)-3-(3,4-diethoxyphenyl) propiolamide (12). Yield: $79 \%$ (white solid); $\mathrm{mp}=185-183{ }^{\circ} \mathrm{C}$. Major isomer: ${ }^{1} \mathrm{H}-\mathrm{NMR}(600 \mathrm{MHz}$, DMSO-d 6 ) $\delta 10.64$ (s, 1H, N1-H), 9.09 (s, 1H, CONH), 7.14 (dd, J = 8.4, $\left.1.9 \mathrm{~Hz}, 1 \mathrm{H}, \mathrm{H}_{\text {arom }}\right), 7.09$ (d, $\left.J=2.1 \mathrm{~Hz}, 1 \mathrm{H}, \mathrm{H}_{\text {arom }}\right), 7.02\left(\mathrm{~d}, J=8.3 \mathrm{~Hz}, 1 \mathrm{H}, \mathrm{H}_{\text {arom }}\right), 6.25\left(\mathrm{~s}, 2 \mathrm{H}, \mathrm{NH}_{2}\right), 4.41(\mathrm{~d}, J=2.4 \mathrm{~Hz}, 2 \mathrm{H}$, $\left.\mathrm{H}_{\text {propargyl }}\right), 4.09-4.01\left(\mathrm{~m}, 4 \mathrm{H}, 2 \times \mathrm{OCH}_{2}\right), 3.02\left(\mathrm{t}, J=2.4 \mathrm{~Hz}, 1 \mathrm{H}, \mathrm{H}_{\text {propargyl }}\right), 1.34-1.31(\mathrm{~m}, 6 \mathrm{H}, 2 \times$ $\left.\mathrm{OCH}_{2} \underline{\mathrm{CH}}_{3}\right) .{ }^{13} \mathrm{C}-\mathrm{NMR}\left(151 \mathrm{MHz}, \mathrm{DMSO}-d_{6}\right) \delta 159.3,153.0,150.7,150.2,149.1,147.9,125.8\left(\mathrm{C}_{\text {arom }}\right)$, 116.2 ( $\left.\mathrm{C}_{\text {arom }}\right), 113.1\left(\mathrm{C}_{\text {arom }}\right), 111.5$ ( $\left.\mathrm{C}_{\text {arom }}\right), 85.5$ (C5 or $\left.\mathrm{C}_{\text {alkyne }}\right), 84.7$ (C5 or $\left.\mathrm{C}_{\text {alkyne }}\right), 83.7$ (C5 or $\left.\mathrm{C}_{\text {alkyne }}\right)$, $79.9\left(\mathrm{C}_{\text {propargyl }}\right), 72.5\left(\mathrm{C}_{\text {propargyl }}\right), 63.8\left(2 \mathrm{C}, \mathrm{OCH}_{2}\right), 28.9\left(\mathrm{~N} 1-\mathrm{CH}_{2}\right), 14.6\left(2 \mathrm{C}, \mathrm{OCH}_{2} \mathrm{CH}_{3}\right)$. Minor isomer: ${ }^{1} \mathrm{H}-\mathrm{NMR}\left(600 \mathrm{MHz}, \mathrm{DMSO}-d_{6}\right) \delta 10.72$ (s, 1H, N1-H), 8.45 (s, 1H, CONH), 6.97-6.90 (m, 2H, Harom), $6.82\left(\mathrm{~d}, J=1.8 \mathrm{~Hz}, 1 \mathrm{H}, \mathrm{H}_{\text {arom }}\right), 6.50\left(\mathrm{~s}, 2 \mathrm{H}, \mathrm{NH}_{2}\right), 4.51-4.44\left(\mathrm{~m}, 2 \mathrm{H}, \mathrm{H}_{\text {propargyl }}\right), 4.05-4.02\left(\mathrm{~m}, 2 \mathrm{H}, \mathrm{OCH}_{2}\right)$ $3.98\left(\mathrm{q}, J=7.4 \mathrm{~Hz}, 2 \mathrm{H}, \mathrm{OCH}_{2}\right), 3.02-3.01\left(\mathrm{~m}, 1 \mathrm{H}, \mathrm{H}_{\text {propargyl }}\right), 1.32-1.28\left(\mathrm{~m}, 6 \mathrm{H}, \mathrm{OCH}_{2} \mathrm{CH}_{3}\right) .{ }^{13} \mathrm{C}-\mathrm{NMR}$ $\left(151 \mathrm{MHz}, \mathrm{DMSO}-d_{6}\right) \delta 160.3,157.8,157.8,151.9,150.2,149.1,147.8,126.0\left(\mathrm{C}_{\text {arom }}\right), 116.2\left(\mathrm{C}_{\text {arom }}\right), 113.0$ $\left(\mathrm{C}_{\text {arom }}\right), 111.4$ ( $\left.\mathrm{C}_{\text {arom }}\right), 87.4$ (C5 or $\left.\mathrm{C}_{\text {alkyne }}\right), 87.1$ (C5 or $\left.\mathrm{C}_{\text {alkyne }}\right), 81.8$ (C5 or $\left.\mathrm{C}_{\text {alkyne }}\right), 79.9$ ( $\left.\mathrm{C}_{\text {propargyl }}\right)$, $72.4\left(\mathrm{C}_{\text {propargyl }}\right), 63.9\left(2 \mathrm{C}, \mathrm{OCH}_{2}\right), 28.9\left(\mathrm{~N} 1-\mathrm{CH}_{2}\right), 14.5\left(2 \mathrm{C}, \mathrm{OCH}_{2} \mathrm{CH}_{3}\right)$. HRMS (ESI-QTOF) calculated for $\mathrm{C}_{20} \mathrm{H}_{20} \mathrm{~N}_{4} \mathrm{O}_{5}[\mathrm{M}+\mathrm{H}]^{+}$: 397.1504; found: 397.1506 .

N-(6-Amino-1,3-dimethyl-2,4-dioxo-1,2,3,4-tetrahydropyrimidin-5-yl)-3-(3,4-diethoxyphenyl) propiolamide (13). Yield: $88 \%$ (white solid); $\mathrm{mp}=220-223{ }^{\circ} \mathrm{C}$. Major isomer: ${ }^{1} \mathrm{H}-\mathrm{NMR}(600 \mathrm{MHz}$, DMSO- $\left.d_{6}\right) \delta 9.08(\mathrm{~s}, 1 \mathrm{H}, \mathrm{CONH}), 7.16\left(\mathrm{dd}, J=8.3,2.0 \mathrm{~Hz}, 1 \mathrm{H}, \mathrm{H}_{\text {arom }}\right), 7.11\left(\mathrm{~d}, J=1.9 \mathrm{~Hz}, 1 \mathrm{H}, \mathrm{H}_{\text {arom }}\right.$ ), $7.03\left(\mathrm{~d}, J=8.8 \mathrm{~Hz}, 2 \mathrm{H}, \mathrm{H}_{\text {arom }}\right), 6.76\left(\mathrm{~s}, 2 \mathrm{H}, \mathrm{NH}_{2}\right), 4.07\left(\mathrm{dq}, J=16.9,7.0 \mathrm{~Hz}, 4 \mathrm{H}, 2 \times \mathrm{OCH}_{2}\right), 3.31(\mathrm{~s}, 3 \mathrm{H}$, $\left.\mathrm{CH}_{3}\right), 3.12\left(\mathrm{~s}, 3 \mathrm{H}, \mathrm{CH}_{3}\right), 1.34\left(\mathrm{td}, J=7.0,2.7 \mathrm{~Hz}, 6 \mathrm{H}, 2 \times \mathrm{OCH}_{2} \underline{\mathrm{CH}}_{3}\right) .{ }^{13} \mathrm{C}-\mathrm{NMR}\left(151 \mathrm{MHz}, \mathrm{DMSO}-d_{6}\right) \delta$ $158.9,153.3,152.1,150.5,150.2,147.9,125.8\left(\mathrm{C}_{\text {arom }}\right), 116.2\left(\mathrm{C}_{\text {arom }}\right), 113.1\left(\mathrm{C}_{\text {arom }}\right), 111.6\left(\mathrm{C}_{\text {arom }}\right), 86.1(\mathrm{C} 5$ or $\left.\mathrm{C}_{\text {alkyne }}\right), 84.5$ (C5 or $\left.\mathrm{C}_{\text {alkyne }}\right), 83.9\left(\mathrm{C} 5\right.$ or $\left.\mathrm{C}_{\text {alkyne }}\right), 63.9\left(2 \mathrm{C}, \mathrm{OCH}_{2}\right), 30.0\left(\mathrm{CH}_{3}\right), 27.5\left(\mathrm{CH}_{3}\right), 14.6(2 \mathrm{C}$, $\left.\mathrm{OCH}_{2} \mathrm{CH}_{3}\right)$. Minor isomer: ${ }^{1} \mathrm{H}-\mathrm{NMR}\left(600 \mathrm{MHz}, \mathrm{DMSO}-d_{6}\right) \delta 8.46(\mathrm{~s}, 1 \mathrm{H}, \mathrm{CONH}), 7.04\left(\mathrm{~s}, 1 \mathrm{H}, \mathrm{H}_{\text {arom }}\right)$, $6.96\left(\mathrm{~d}, J=8.4 \mathrm{~Hz}, 1 \mathrm{H}, \mathrm{H}_{\text {arom }}\right), 6.85\left(\mathrm{dd}, J=8.3,1.9 \mathrm{~Hz}, 1 \mathrm{H}, \mathrm{H}_{\text {arom }}\right), 6.75\left(\mathrm{~s}, 2 \mathrm{H}, \mathrm{NH}_{2}\right), 4.07-4.05(\mathrm{~m}$, $\left.2 \mathrm{H}, \mathrm{OCH}_{2}\right), 3.95\left(\mathrm{q}, \mathrm{J}=6.9 \mathrm{~Hz}, 2 \mathrm{H}, \mathrm{OCH}_{2}\right), 3.34\left(\mathrm{~s}, 3 \mathrm{H}, \mathrm{CH}_{3}\right), 3.15\left(\mathrm{~s}, 3 \mathrm{H}, \mathrm{CH}_{3}\right), 1.32-1.28(\mathrm{~m}, 6 \mathrm{H}, 2 \times$ $\left.\mathrm{OCH}_{2} \underline{\mathrm{CH}}_{3}\right) .{ }^{13} \mathrm{C}-\mathrm{NMR}\left(151 \mathrm{MHz}, \mathrm{DMSO}-d_{6}\right) \delta 160.0,158.0,153.2,150.5,150.2,147.9,125.8\left(\mathrm{C}_{\text {arom }}\right)$, 116.1 ( $\left.\mathrm{C}_{\text {arom }}\right), 113.1$ ( $\left.\mathrm{C}_{\text {arom }}\right), 111.5$ ( $\left.\mathrm{C}_{\text {arom }}\right), 88.1$ (C5 or $\left.\mathrm{C}_{\text {alkyne }}\right), 86.9$ (C5 or $\left.\mathrm{C}_{\text {alkyne }}\right), 82.1$ (C5 or $\left.\mathrm{C}_{\text {alkyne }}\right)$, $63.8\left(2 \mathrm{C}, \mathrm{OCH}_{2}\right), 30.1\left(\mathrm{CH}_{3}\right), 27.6\left(\mathrm{CH}_{3}\right), 14.5\left(2 \mathrm{C}, \mathrm{OCH}_{2} \mathrm{CH}_{3}\right)$. HRMS (ESI-QTOF) calculated for $\mathrm{C}_{19} \mathrm{H}_{22} \mathrm{~N}_{4} \mathrm{O}_{5}[\mathrm{M}+\mathrm{H}]^{+}$: 387.1663; found: 387.1668 .

N-(6-Amino-3-ethyl-2,4-dioxo-1,2,3,4-tetrahydropyrimidin-5-yl)cinnamamide (14). Yield: 80\% (off-white solid); mp > $320{ }^{\circ} \mathrm{C} ;{ }^{1} \mathrm{H}-\mathrm{NMR}\left(500 \mathrm{MHz}, \mathrm{DMSO}-d_{6}\right) \delta 10.43$ (s, 1H, N1-H), 8.68 (s, 1H, CONH), $7.58\left(\mathrm{~d}, J=7.4 \mathrm{~Hz}, 2 \mathrm{H}, \mathrm{H}_{\text {arom }}\right), 7.50-7.37\left(\mathrm{~m}, 4 \mathrm{H}, \mathrm{H}_{\text {arom }}+\mathrm{H}_{\text {vinyl }}\right), 6.83$ (d, J = 15.9 Hz, 1H, $\left.\mathrm{H}_{\text {vinyl }}\right), 5.99$ $\left(\mathrm{s}, 2 \mathrm{H}, \mathrm{NH}_{2}\right), 3.74\left(\mathrm{q}, J=6.5 \mathrm{~Hz}, 2 \mathrm{H}, \mathrm{CH}_{2}\right), 1.06\left(\mathrm{t}, J=6.7 \mathrm{~Hz}, 3 \mathrm{H}, \mathrm{CH}_{3}\right) .{ }^{13} \mathrm{C}-\mathrm{NMR}\left(\mathrm{DMSO}-d_{6}, 126 \mathrm{MHz}\right)$ $\delta 164.9(\mathrm{CON}), 160.3(\mathrm{C} 6), 149.7(\mathrm{CO}), 149.5(\mathrm{CO}), 138.8\left(\mathrm{C}_{\text {vinyl }}\right.$ or $\left.\mathrm{C}_{\text {arom }}\right), 135.0\left(\mathrm{C}_{\text {vinyl }}\right.$ or $\left.\mathrm{C}_{\text {arom }}\right), 129.4$ $\left(\mathrm{C}_{\text {vinyl }}\right.$ or $\left.\mathrm{C}_{\text {arom }}\right), 129.0\left(2 \mathrm{C}, \mathrm{C}_{\text {arom }}\right), 127.4\left(2 \mathrm{C}, \mathrm{C}_{\text {arom }}\right), 122.4\left(\mathrm{C}_{\text {vinyl }}\right.$ or $\left.\mathrm{C}_{\text {arom }}\right), 87.4(\mathrm{C} 5), 34.4\left(\mathrm{~N}_{3}-\mathrm{CH}_{2}\right)$, $13.2\left(\mathrm{CH}_{3}\right)$. HRMS (ESI-QTOF) calculated for $\mathrm{C}_{15} \mathrm{H}_{16} \mathrm{~N}_{4} \mathrm{O}_{3}[\mathrm{M}+\mathrm{H}]^{+}$: 301.1295; found: 301.1294 .

N-(6-Amino-3-ethyl-2,4-dioxo-1,2,3,4-tetrahydropyrimidin-5-yl)-3-phenylpropanamide (15). Yield: $90 \%$ (white solid); mp > $320{ }^{\circ} \mathrm{C} ;{ }^{1} \mathrm{H}-\mathrm{NMR}\left(500 \mathrm{MHz}, \mathrm{DMSO}-d_{6}\right) \delta 10.38$ (s, 1H, N1-H), 8.39 (s, $1 \mathrm{H}$, $\mathrm{CONH}), 7.28\left(\mathrm{t}, J=7.4 \mathrm{~Hz}, 2 \mathrm{H}, \mathrm{H}_{\text {arom }}\right), 7.24\left(\mathrm{~d}, J=6.9 \mathrm{~Hz}, 2 \mathrm{H}, \mathrm{H}_{\text {arom }}\right), 7.18\left(\mathrm{t}, J=7.1 \mathrm{~Hz}, 1 \mathrm{H}, \mathrm{H}_{\text {arom }}\right)$, 
$5.82\left(\mathrm{~s}, 2 \mathrm{H}, \mathrm{NH}_{2}\right), 3.73\left(\mathrm{q}, J=6.9 \mathrm{~Hz}, 2 \mathrm{H}, \mathrm{N} 3-\mathrm{CH}_{2}\right), 2.91-2.80\left(\mathrm{~m}, 2 \mathrm{H}, \mathrm{CH}_{2}\right), 2.53(\mathrm{dd}, J=9.2,7.0 \mathrm{~Hz}$, $\left.2 \mathrm{H}, \mathrm{CH}_{2}\right), 1.04\left(\mathrm{t}, J=7.0 \mathrm{~Hz}, 3 \mathrm{H}, \mathrm{CH}_{3}\right) .{ }^{13} \mathrm{C}-\mathrm{NMR}$ (DMSO-d $\left.d_{6}, 126 \mathrm{MHz}\right) \delta 171.7(\mathrm{CON}), 160.4(\mathrm{C} 6)$, $149.9(\mathrm{CO}), 149.6(\mathrm{CO}), 141.5\left(\mathrm{C}_{\text {arom }}\right), 128.3$ (2C, $\left.\mathrm{C}_{\text {arom }}\right), 128.1$ (2C, $\left.\mathrm{C}_{\text {arom }}\right), 125.8$ ( $\left.\mathrm{C}_{\text {arom }}\right), 87.2$ (C5), 36.8 $\left(\mathrm{CH}_{2}\right), 34.3\left(\mathrm{~N} 3-\mathrm{CH}_{2}\right), 30.9\left(\mathrm{CH}_{2}\right), 13.2\left(\mathrm{CH}_{3}\right)$. HRMS (ESI-QTOF) calculated for $\mathrm{C}_{15} \mathrm{H}_{18} \mathrm{~N}_{4} \mathrm{O}_{3}[\mathrm{M}+\mathrm{H}]^{+}$: 303.1452; found: 303.1454 .

N-(6-Amino-3-ethyl-2,4-dioxo-1,2,3,4-tetrahydropyrimidin-5-yl)benzamide (16). Yield: 87\% (yellowish solid; mp > $320{ }^{\circ} \mathrm{C} ;{ }^{1} \mathrm{H}-\mathrm{NMR}\left(500 \mathrm{MHz}\right.$, DMSO- $d_{6}$ ) $\delta 10.38$ (s, 1H, N1-H), 8.86 (s, 1H, CONH), 7.99-7.91 $\left(\mathrm{m}, 2 \mathrm{H}, \mathrm{H}_{\text {arom }}\right), 7.56-7.51\left(\mathrm{~m}, 1 \mathrm{H}, \mathrm{H}_{\text {arom }}\right), 7.47\left(\mathrm{t}, J=7.5 \mathrm{~Hz}, 2 \mathrm{H}, \mathrm{H}_{\text {arom }}\right), 6.06\left(\mathrm{~s}, 2 \mathrm{H}, \mathrm{NH}_{2}\right), 3.75(\mathrm{q}$, $\left.J=7.0 \mathrm{~Hz}, 2 \mathrm{H}, \mathrm{N} 3-\mathrm{CH}_{2}\right), 1.06\left(\mathrm{t}, J=7.0 \mathrm{~Hz}, 3 \mathrm{H}, \mathrm{CH}_{3}\right) .{ }^{13} \mathrm{C}-\mathrm{NMR}\left(126 \mathrm{MHz}, \mathrm{DMSO}-d_{6}\right) \delta 166.4(\mathrm{CON})$, 160.5 (C6), 150.4 (CO), 149.7 (CO), 134.5 ( $\left.\mathrm{C}_{\text {arom }}\right), 131.1$ ( $\left.\mathrm{C}_{\text {arom }}\right), 128.0\left(\mathrm{C}_{\text {arom }}\right), 127.8$ ( $\left.\mathrm{C}_{\text {arom }}\right), 87.1$ (C5), $34.4\left(\mathrm{~N} 3-\mathrm{CH}_{2}\right), 13.3\left(\mathrm{CH}_{3}\right)$. HRMS (ESI-QTOF) calculated for $\mathrm{C}_{13} \mathrm{H}_{14} \mathrm{~N}_{4} \mathrm{O}_{3}[\mathrm{M}+\mathrm{H}]^{+}$: 275.1139; found: 275.1142 .

$\mathrm{N}$-(6-Amino-3-ethyl-2,4-dioxo-1,2,3,4-tetrahydropyrimidin-5-yl)-2-phenylacetamide (17). Yield: 80\% (white solid); $\mathrm{mp}>320{ }^{\circ} \mathrm{C} ;{ }^{1} \mathrm{H}-\mathrm{NMR}\left(500 \mathrm{MHz}, \mathrm{DMSO}-d_{6}\right) \delta 10.39$ (s, $\left.1 \mathrm{H}, \mathrm{N} 1-\mathrm{H}\right), 8.58(\mathrm{~s}, 1 \mathrm{H}, \mathrm{CONH})$, 7.35-7.31 (m, 2H, $\left.\mathrm{H}_{\text {arom }}\right), 7.28\left(\mathrm{~m}, 2 \mathrm{H}, \mathrm{H}_{\text {arom }}\right), 7.23-7.19\left(\mathrm{~m}, 1 \mathrm{H}, \mathrm{H}_{\text {arom }}\right), 5.90\left(\mathrm{~s}, 2 \mathrm{H}, \mathrm{NH}_{2}\right), 3.71$ $\left(\mathrm{q}, J=7.0 \mathrm{~Hz}, 2 \mathrm{H}, \mathrm{N} 3-\mathrm{CH}_{2}\right), 3.56\left(\mathrm{~s}, 2 \mathrm{H}, \mathrm{CH}_{2}\right), 1.03\left(\mathrm{t}, J=7.0 \mathrm{~Hz}, 3 \mathrm{H}, \mathrm{CH}_{3}\right) .{ }^{13} \mathrm{C}-\mathrm{NMR}\left(\mathrm{DMSO}-d_{6}\right.$, $126 \mathrm{MHz}) \delta 170.6(\mathrm{CON}), 160.5(\mathrm{C} 6), 150.1(\mathrm{CO}), 149.7(\mathrm{CO}), 136.6\left(\mathrm{C}_{\text {arom }}\right), 129.4\left(\mathrm{C}_{\text {arom }}\right), 128.2\left(\mathrm{C}_{\text {arom }}\right)$, $126.3\left(\mathrm{C}_{\text {arom }}\right), 87.5(\mathrm{C} 5), 42.1\left(\mathrm{COCH}_{2}\right), 34.5\left(\mathrm{~N} 3-\mathrm{CH}_{2}\right), 13.4\left(\mathrm{CH}_{3}\right)$. HRMS (ESI-QTOF) calculated for $\mathrm{C}_{14} \mathrm{H}_{16} \mathrm{~N}_{4} \mathrm{O}_{3}[\mathrm{M}+\mathrm{H}]^{+}$: 289.1295; found: 289.1304 .

Supplementary Materials: The following data are available online. Figure S1-S15: NMR spectra, Figure S16: DHPLC analyses of $\mathbf{1 2}$ at $205 \mathrm{~nm}$, Figure S17: UV-spectrum of compound 12. Table S1-S3: Crystal data and structure refinement for compound 8. Scheme S1-S2: Synthesis of diaminouracil derivatives.

Author Contributions: D.M. synthesized the compounds and analyzed the NMR spectra. S.G. performed the DFT calculations. G.S. measured the X-ray crystal structure. C.E.M. supervised the experiments. D.M. and C.E.M. wrote the manuscript, all coauthors contributed to writing.

Funding: D.M. and C.E.M. were supported by the BMBF (German Federal Ministry for Education and Research) within the "Neuroallianz" consortium of the BioPharma initiative.

Acknowledgments: We thank Andreas Schneider for the DHPLC measurements, Jörg Hockemeyer for helpful discussions, and Senada Nozinovic, Marion Schneider, Sabine Terhart-Krabbe, and Annette Reiner for recording NMR and MS data.

Conflicts of Interest: No conflicts of interest.

\section{References}

1. Boison, D. Adenosine as a neuromodulator in neurological diseases. Curr. Opin. Pharmacol. 2008, 8, 2-7. [CrossRef] [PubMed]

2. Morelli, M.; Carta, A.R.; Jenner, P. Adenosine $A_{2 A}$ receptors and Parkinson's disease. Handb. Exp. Pharmacol. 2009, 193, 589-615.

3. Rahman, A. The role of adenosine in Alzheimer's disease. Curr. Neuropharmacol. 2009, 7, 207-216. [CrossRef] [PubMed]

4. Leone, R.D.; Lo, Y.-C.; Powell, J.D. $\mathrm{A}_{2 \mathrm{~A}} \mathrm{R}$ antagonists: Next generation checkpoint blockade for cancer immunotherapy. Comput. Struct. Biotechnol. J. 2015, 13, 265-272. [CrossRef] [PubMed]

5. Franco, R.; Oñatibia-Astibia, A.; Martínez-Pinilla, E. Health benefits of methylxanthines in cacao and chocolate. Nutrients 2013, 5, 4159-4173. [CrossRef] [PubMed]

6. Dungo, R.; Deeks, E.D. Istradefylline: First global approval. Drugs 2013, 73, 875-882. [CrossRef] [PubMed]

7. LeWitt, P.A.; Guttman, M.; Tetrud, J.W.; Tuite, P.J.; Mori, A.; Chaikin, P.; Sussman, N.M. Adenosine A $2 A$ receptor antagonist istradefylline (KW-6002) reduces "off" time in Parkinsons disease: A double-blind, randomized, multicenter clinical trial (6002-US-005). Ann. Neurol. 2008, 63, 295-302. [CrossRef]

8. Sauer, R.; Maurinsh, J.; Reith, U.; Fülle, F.; Klotz, K.-N.; Müller, C.E. Water-soluble phosphate prodrugs of 1-propargyl-8-styrylxanthine derivatives, $\mathrm{A}_{2 \mathrm{~A}}$-selective adenosine receptor antagonists. J. Med. Chem. 2000, 43, 440-448. [CrossRef] 
9. Hockemeyer, J.; Burbiel, J.C.; Müller, C.E. Multigram-scale syntheses, stability, and photoreactions of $A_{2 A}$ adenosine receptor antagonists with 8-styrylxanthine structure: potential drugs for Parkinson's Disease. J. Org. Chem. 2004, 69, 3308-3318. [CrossRef]

10. Müller, C.E.; Schobert, U.; Hipp, J.; Geis, U.; Frobenius, W.; Pawlowski, M. Configurationally stable analogs of styrylxanthines as $\mathrm{A}_{2 \mathrm{~A}}$ adenosine receptor antagonist. Eur. J. Med. Chem. 1997, 32, 709-719. [CrossRef]

11. Müller, C.E.; Hockemeyer, J.; Tzvetkov, N.; Burbiel, J.C. 8-Ethinylxanthine Derivatives as Selective $A_{2 A}$ Receptor Antagonists. WO Patent WO2008077557A1, 19 December 2007.

12. Lopes, B.A.; Miguez, E.; Kümmerle, E.A.; Rumjanek, M.V.; Fraga, A.C.; Barreiro, J.E. Characterization of amide bond conformers for a novel heterocyclic template of $N$-acylhydrazone derivatives. Molecules 2013, 18, 11683-11704. [CrossRef] [PubMed]

13. Quintanilla-Licea, R.; Colunga-Valladares, J.; Caballero-Quintero, A.; Rodríguez-Padilla, C.; Tamez-Guerra, R.; Gomez-Flores, R.; Waksman, N. NMR detection of isomers arising from restricted rotation of the $C-N$ amide bond of $\mathrm{N}$-formyl-o-toluidine and N,N-bis-formyl-o-tolidine. Molecules 2002, 7, 662-673. [CrossRef]

14. Mphahlele, J.M.; Maluleka, M.M.; Rhyman, L.; Ramasami, P.; Mampa, M.R. Spectroscopic, DFT, and XRD studies of hydrogen bonds in $\mathrm{N}$-unsubstituted 2-aminobenzamides. Molecules 2017, 22, 83. [CrossRef] [PubMed]

15. Laursen, J.S.; Engel-Andreasen, J.; Fristrup, P.; Harris, P.; Olsen, C.A. Cis-trans amide bond rotamers in beta-peptoids and peptoids: Revaluation of stereoelectronic effects in backbone and side chains. J. Am. Chem. Soc. 2013, 135, 2835-2844. [CrossRef] [PubMed]

16. Hu, X.; Zhang, W.; Carmichael, I.; Serianni, A.S. Amide cis-trans iosomerization in aqueous solutions of methyl $N$-formyl- $d$-glucosaminides and methyl $N$-acetyl- $d$-glucosaminides: Chemical equilibria and exchange kinetics. J. Am. Chem. Soc. 2010, 132, 4641-4652. [CrossRef]

17. Marx, D.; Wingen, L.M.; Schnakenburg, G.; Müller, C.E.; Scholz, M.S. Fast, efficient, and versatile synthesis of 6-amino-5-carboxamidouracils as precursors for 8-substituted xanthines. Front. Chem. 2019, 7, 1-15. [CrossRef]

18. El-Sabbagh, O.I.; El-Sadek, M.E.; El-Kalyoubi, S.; Ismail, I. Synthesis, DNA binding and antiviral activity of new uracil, xanthine, and pteridine derivatives. Arch. Pharm. 2007, 340, 26-31. [CrossRef]

19. Hayallah, A.M.; Sandoval-Ramírez, J.; Reith, U.; Schobert, U.; Preiss, B.; Schumacher, B.; Daly, J.W.; Müller, C.E. 1,8-Disubstituted xanthine derivatives: Synthesis of potent $\mathrm{A}_{2 \mathrm{~B}}$-selective adenosine receptor antagonists. J. Med. Chem. 2002, 45, 1500-1510. [CrossRef]

20. Yang, S.-M.; Yasgar, A.; Miller, B.; Lal-Nag, M.; Brimacombe, K.; Hu, X.; Sun, H.; Wang, A.; Xu, X.; Nguyen, K.; et al. Discovery of NCT-501, a potent and selective theophylline-based inhibitor of aldehyde dehydrogenase 1A1 (ALDH1A1). J. Med. Chem. 2015, 58, 5967-5978. [CrossRef]

21. Poulsen, A.; Ho, S.Y.; Wang, W.; Alam, J.; Jeyaraj, D.A.; Ang, S.H.; Tan, E.S.W.; Lin, G.R.; Cheong, V.W.W.; Ke, Z.; et al. Pharmacophore model for Wnt/Porcupine inhibitors and its use in drug design. J. Chem. Inf. Model. 2015, 55, 1435-1448. [CrossRef] [PubMed]

22. Novak, P.; Skare, D.; Sekušak, S.; Vikić-Topić, D. Substituent, temperature and solvent effects on keto-enol equilibrium in symmetrical pentane-1,3,5-triones. Nuclear magnetic resonance and theoretical studies. Croatica Chemica Acta 2000, 73, 1153-1170.

23. Krishnan, V.V.; Thompson, W.B.; Goto, J.J.; Maitra, K.; Maitra, S. Modulations in restricted amide rotation by steric induced conformational trapping. Chem. Phys. Lett. 2012, 523, 124-127. [CrossRef] [PubMed]

24. Gorse, A.-D.; Pesquer, M. A theoretical study of aniline and some derivatives in their ground states. J. Mol. Struct. Theochem. 1993, 281, 21-32. [CrossRef]

25. Gasparro, F.P.; Kolodny, N.H. NMR determination of the rotational barrier in $N, N$-dimethylacetamide. A physical chemistry experiment. J. Chem. Educ. 1977, 54, 258. [CrossRef]

26. Mamat, C.; Pretze, M.; Gott, M.; Köckerling, M. Synthesis, dynamic NMR characterization and XRD studies of novel $N, N^{\prime}$-substituted piperazines for bioorthogonal labeling. Beilstein J. Org. Chem. 2016, 12, 2478-2489. [CrossRef]

27. Modarresi-Alam, A.R.; Najafi, P.; Rostamizadeh, M.; Keykha, H.; Bijanzadeh, H.-R.; Kleinpeter, E. Dynamic ${ }^{1} \mathrm{H}$ NMR Study of the barrier to rotation about the $\mathrm{C}-\mathrm{N}$ bond in primary carbamates and its solvent dependence. J. Org. Chem. 2007, 72, 2208-2211. [CrossRef] 
28. Stærk, D.; Norrby, P.-O.; Jaroszewski, J.W. Conformational analysis of indole alkaloids corynantheine and dihydrocorynantheine by dynamic ${ }^{1} \mathrm{H}$ NMR spectroscopy and computational methods: steric effects of ethyl vs vinyl group. J. Org. Chem. 2001, 66, 2217-2221. [CrossRef]

29. Ahlrichs, R.; Bär, M.; Häser, M.; Horn, H.; Kölmel, C. Electronic structure calculations on workstation computers: The program system turbomole. Chem. Phys. Lett. 1989, 162, 165-169. [CrossRef]

30. Neese, F. ORCA - An ab Initio, DFT and Semiempirical SCF-MO Package; Max Planck Institute for Bioinorganic Chemistry: Mülheim an der Ruhr, Germany, 2012.

31. Grimme, S.; Brandenburg, J.G.; Bannwarth, C.; Hansen, A. Consistent structures and interactions by density functional theory with small atomic orbital basis sets. J. Chem. Phys. 2015, 143, 054107. [CrossRef]

32. Grimme, S.; Bannwarth, C.; Dohm, S.; Hansen, A.; Pisarek, J.; Pracht, P.; Seibert, J.; Neese, F. Fully automated quantum-chemistry-based computation of spin-spin-coupled nuclear magnetic resonance spectra. Angew. Chem. Int. Ed. Engl. 2017, 56, 14763-14769. [CrossRef] [PubMed]

33. Grimme, S.; Bannwarth, C.; Shushkov, P. A robust and accurate tight-binding quantum chemical method for structures, vibrational frequencies, and noncovalent interactions of large molecular systems parametrized for all spd-block elements $(Z=1-86)$. J. Chem. Theory Comput. 2017, 13, 1989-2009. [CrossRef] [PubMed]

34. Zimmerman, P. Reliable transition state searches integrated with the growing string method. J. Chem. Theory Comput. 2013, 9, 3043-3050. [CrossRef] [PubMed]

35. Grimme, S. XTB, a Tight-Binding Quantum Chemistry Code for Large Molecules, version 6.1; University of Bonn: Bonn, Germany, 2019.

36. Weigend, F.; Ahlrichs, R. Balanced basis sets of split valence, triple zeta valence and quadruple zeta valence quality for H to Rn: Design and assessment of accuracy. Phys. Chem. Chem. Phys. 2005, 7, 3297-3305. [CrossRef] [PubMed]

37. Kozuch, S.; Gruzman, D.; Martin, J.M.L. DSD-BLYP: A general purpose double hybrid density functional including spin component scaling and dispersion correction. J. Phys. Chem. C 2010, 114, 20801-20808. [CrossRef]

38. Grimme, S.; Antony, J.; Ehrlich, S.; Krieg, H. A consistent and accurate ab initio parametrization of density functional dispersion correction (DFT-D) for the 94 elements H-Pu. J. Chem. Phys. 2010, 132, 154104. [CrossRef]

39. Kozuch, S.; Martin, J.M.L. Spin-component-scaled double hybrids: An extensive search for the best fifth-rung functionals blending DFT and perturbation theory. J. Comput. Chem. 2013, 34, 2327-2344. [CrossRef]

40. Goerigk, L.; Hansen, A.; Bauer, C.; Ehrlich, S.; Najibi, A.; Grimme, S. A look at the density functional theory zoo with the advanced GMTKN55 database for general main group thermochemistry, kinetics and noncovalent interactions. Phys. Chem. Chem. Phys. 2017, 19, 32184-32215. [CrossRef]

41. Eichkorn, K.; Treutler, O.; Öhm, H.; Häser, M.; Ahlrichs, R. Auxiliary basis sets to approximate coulomb potentials. Chem. Phys. Lett. 1995, 240, 283-290. [CrossRef]

42. Grimme, S. Supramolecular binding thermodynamics by dispersion-corrected density functional theory. Chem. - Eur. J. 2012, 18, 9955-9964. [CrossRef]

43. Sure, R.; Grimme, S. Corrected small basis set Hartree-Fock method for large systems. J. Comput. Chem. 2013, 34, 1672-1685. [CrossRef] [PubMed]

44. Eckert, F.; Klamt, A. Fast solvent screening via quantum chemistry: COSMO-RS approach. AIChE J. 2004, 48, 369-385. [CrossRef]

45. Becke, A.D. Density-functional exchange-energy approximation with correct asymptotic behavior. Phys. Rev. A Gen. Phys. 1988, 38, 3098-3100. [CrossRef] [PubMed]

46. Sinnecker, S.; Rajendran, A.; Klamt, A.; Diedenhofen, M.; Neese, F. Calculation of solvent shifts on electronic g-tensors with the conductor-like screening model (COSMO) and its self-consistent generalization to real solvents (direct COSMO-RS). J. Phys. Chem. A 2006, 110, 2235-2245. [CrossRef] [PubMed]

Sample Availability: Samples of compound 8a are available from the authors.

(C) 2019 by the authors. Licensee MDPI, Basel, Switzerland. This article is an open access article distributed under the terms and conditions of the Creative Commons Attribution (CC BY) license (http://creativecommons.org/licenses/by/4.0/). 